Prawne i ekonomiczne aspekty migracji, red. Magdalena Butrymowicz, Piotr Kroczek,

Kraków 2016, s. 51-68 (Biblioteczka Prawa, 1).

DOI: http://dx.doi.org/10.15633/9788374385473.04

Romuald Jończy

UNIWERSYTET EKONOMICZNY WE WROCEAWIU

Alicja Dolińska

WYŻSZA SZKOEA BANKOWA WE WROCEAWIU

\title{
Charakter i kierunki migracji pomaturalnych młodzieży na przykładzie województwa dolnośląskiego
}

Problem przemieszczeń przestrzennych ludności Polski, zwłaszcza migracji młodzieży, zyskuje współcześnie na znaczeniu i zaczyna się odciskać coraz silniejszym piętnem na obszarach, których dotyczy. Wśród powodów (nasilenia) tych procesów należy wymienić w pierwszym rzędzie akcesję Polski do Unii Europejskiej i związaną z tym swobodę przemieszczania się do Europy Zachodniej oraz niemal nieograniczony w Polsce dostęp do kształcenia na poziomie wyższym.

Pierwszy z wymienionych powodów sprawił, że po 2004 roku dla Polaków pojawiła się istotna i atrakcyjna możliwość wyjazdu, pracy i zamieszkania w krajach Europy Zachodniej. Z tej możliwości szczególnie chętnie korzysta młodzież, wskazująca jako główne motywy 
migracji zagranicznych względy stricte ekonomiczne - lepszy poziom życia za sprawą dobrze płatnej pracy, ale również zachodnioeuropejskie zdobycze cywilizacyjno-społeczne, odczuwalne chociażby w postaci szerokiego dostępu do świadczeń socjalnych.

Innym i - jak się wydaje niedocenianym - powodem ożywienia migracji, zwłaszcza w wymiarze zewnętrznym, jest w Polsce niemal nieograniczony od kilkunastu lat dostęp do kształcenia na poziomie wyższym. Skutkuje to ogromną liczbą studiujących i olbrzymią liczbą absolwentów studiów, w ostatnich latach porównywalną do liczby urodzeń. Przy tak dużej liczbie absolwentów uczelni wyższych i jednoczesnym nienadążaniu gospodarki z tworzeniem miejsc wysoko kwalifikowanej pracy następuje stopniowe zatłoczenie niektórych segmentów rynku pracy wysoko kwalifikowanej. Coraz częściej zdobywane wykształcenie wyższe nie gwarantuje już dobrego czy nawet jakiegokolwiek zatrudnienia w miejscu zamieszkania i prowadzi do narastającej frustracji absolwentów studiów wyższych, a w konsekwencji szerokich w swojej skali migracji definitywnych. Również samo terytorialne rozmieszczenie ośrodków akademickich w niektórych przypadkach wymusza podejmowanie decyzji migracyjnych, a w niektórych mu sprzyja. Dla młodzieży zamieszkującej obszary peryferyjne podjęcie studiów wiąże się na ogół $\mathrm{z}$ „wyjazdem edukacyjnym” do ośrodka regionalnego, a obrana ścieżka bardzo rzadko, po ukończeniu edukacji, wiąże się z powrotem do rodzinnego domu. Miejsce migracji edukacyjnej staje się tym samym miejscem migracji definitywnej.

Celem niniejszego opracowania jest wskazanie, jak wybór miejsca studiów determinuje decyzje maturzystów o miejscu przyszłego zamieszkania. Na podstawie zaprezentowanego w opracowaniu fragmentu wyniku rozległych badań, przeprowadzonych w wybranych powiatach województwa dolnośląskiego wśród uczniów ostatnich klas liceów ogólnokształcących, dokonano porównania preferowanych 
ośrodków studiów oraz zamierzonych miejsc docelowego zamieszkania. Interpretacja takiego zestawienia pozwala sądzić, że drenaż edukacyjny młodzieży jest jednocześnie początkiem emigracji definitywnej, kierującej się głównie do dużych i postrzeganych jako atrakcyjne ośrodków regionalnych.

\section{Metodyka badań}

Do zebrania materiału empirycznego została zastosowana ilościowa metoda pozyskiwania danych. Wybrano technikę sondażu ankietowego. Dobór próby miał charakter celowy, badaniu empirycznemu poddano maturzystów klas ogólnokształcących ze szkół ulokowanych w wybranych powiatach województwa dolnośląskiego. Wydaje się to zasadne $\mathrm{z}$ tego względu, że właśnie po maturze zapadają najbardziej istotne decyzje dotyczące miejsca i rodzaju dalszej aktywności edukacyjnej lub/i pracowniczej, zaś podjęte wtedy kierunki migracji prowadzą do stałych przemieszczeń.

Badania przeprowadzono na obszarze województwa dolnośląskiego, ponieważ charakteryzuje się ono istotnymi dysproporcjami w poziomie rozwoju społeczno-gospodarczego pomiędzy jego centrum a większością pozostałego obszaru. Województwo to również jest przykładem dobrze wykształconej struktury przestrzennej i osadniczej z silnym ośrodkiem regionalnym (Wrocławiem) i dużymi ośrodkami subregionalnymi o równych cechach (m.in. miasta powojewódzkie: Legnica, Jelenia Góra i Wałbrzych). Ważne wydaje się również położenie geograficzne województwa, umożliwiające stosunkowo szybki dostęp do ważnych europejskich ośrodków gospodarczych i kulturalnych (Berlin, Drezno, Praga, Wiedeń, Budapeszt, Bratysława), co w sumie może mieć wpływ na zwiększoną mobilność w wymiarze międzynarodowym. Sondaż ankietowy przeprowadzono na próbach kontrastowych, co polegało na pobraniu prób z grup 
różniących się z punktu widzenia pewnej istotnej dla badania zmiennej. Kluczowym kryterium doboru próby stała się stopa bezrobocia w poszczególnych powiatach województwa dolnośląskiego. W rezultacie na podstawie dostępnych danych statystycznych wybrano trzy powiaty charakteryzujące się najniższą stopą bezrobocia w województwie dolnośląskim oraz dla kontrastu trzy, w których stopa bezrobocia osiągnęła najwyższy poziom.

Wyboru dokonano na podstawie dostępnych danych statystycznych na koniec 2011 roku. Do pierwszej grupy zakwalifikowały się dwa miasta tworzące zarazem powiaty: Wrocław (stopa bezrobocia 5,5 proc.) i Jelenia Góra (stopa bezrobocia 10,9 proc.) oraz powiat lubiński (stopa bezrobocia 9,7 proc.), natomiast drugą grupę tworzą następujące powiaty: lwówecki (stopa bezrobocia 24,7 proc.), kłodzki (stopa bezrobocia 24,7 proc.) i górowski (stopa bezrobocia 26,6 proc.). Badanie zostało zrealizowane w następujących ośrodkach: Jelenia Góra, Wrocław, Lubin, Góra, Kudowa Zdrój, Bystrzyca Kłodzka, Kłodzko, Lwówek Śląski, Gryfów Śląski, Rakowice Wielkie, Lubomierz.

Badanie ankietowe zostało przeprowadzone łącznie w 17 szkołach i objęło 815 maturzystów. Sondaż ankietowy przeprowadzono w marcu i kwietniu 2012 roku.

\section{Wyniki badań}

Analiza wyników zrealizowanych badań będzie się odbywać w omówionych wcześniej dwóch grupach powiatów, a dla większej przejrzystości opracowania będą używane również pojęcia I grupa powiatów, pod którą rozumieć należy tę skupiającą trzy powiaty charakteryzujące się najniższą stopą bezrobocia w województwie dolnośląskim (powiat $\mathrm{m}$. Wrocław, $\mathrm{m}$. Jelenia Góra, powiat lubiński) oraz II grupa powiatów obejmująca trzy powiaty cechujące się najwyższą stopą bezrobocia (górowski, kłodzki, lwówecki). 
W pierwszym z zaprezentowanych pytań badawczych respondentów zapytano o ich zamiary na najbliższą przyszłość po ukończeniu liceum (rys. 1). Ankietowani mogli wybrać, które spośród najbardziej prawdopodobnych aktywności zamierzają podjąć tuż po maturze: „kontynuować naukę, nie podejmując pracy”; „kontynuować naukę i jednocześnie podjąć pracę”, „podjąć pracę, nie kontynuując nauki” czy „robić coś innego” (tu badani mogli samodzielnie wpisać, co zamierzają robić po ukończeniu szkoły średniej).

Rysunek 1. Zamiary na najbliższą przyszłość - deklarowane przez młodzież objętą badaniem

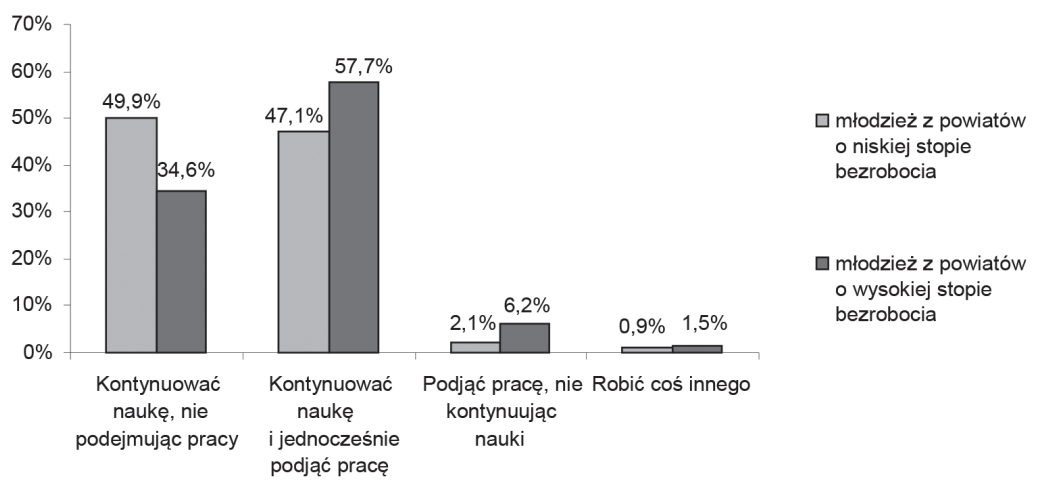

Źródło: Opracowanie własne na podstawie wyników badań.

Porównanie grup badanych z obszarów o niskiej i wysokiej stopie bezrobocia wskazało, że wśród maturzystów z I grupy powiatów zdecydowanie większy jest odsetek osób zamierzających kontynuować naukę bez podejmowania pracy (49,9 proc.), a nieco niższy odsetek mających zamiar łączyć kształcenie z pracą (47,1 proc.) oraz wyłącznie pracować $(2,1$ proc.). Z kolei wśród osób pochodzących z II grupy powiatów zdecydowanie większa jest skłonność do łączenia nauki z pracą (ponad 57 proc.) i do podjęcia wyłącznie pracy (6,2 proc.), zaś relatywnie mniejszy jest udział zamierzających się kształcić bez 
podejmowania pracy (34,5 proc.). Sądzić należy, że zróżnicowanie to wynika $z$ odmiennej sytuacji na rynku pracy na obszarach zamieszkiwanych przez młodzież objętą badaniem. Na obszarach odznaczających się niskim poziomem bezrobocia przede wszystkim większa zamożność rodzin, a co za tym idzie wyższa jakość życia, a także mniejsza liczba posiadanego potomstwa (jak wskazują cechy demograficzne respondentów) sprawiają, że rodzice maturzystów $\mathrm{w}$ większym stopniu mogą pozwolić sobie na materialne wspieranie dzieci podczas ich dalszego kształcenia. Oznacza to, że sytuacja na regionalnych rynkach pracy ma związek z decyzjami dotyczącymi podejmowania zatrudnienia tuż po ukończeniu szkoły średniej. Porównanie odpowiedzi badanych nasuwa także dwa inne ważne wnioski. Po pierwsze fakt, że na obszarze o wyższym bezrobociu większa część młodzieży będzie poszukiwała pracy od razu po maturze, spowoduje prawdopodobnie jego wzrost, gdyż część młodzieży najprawdopodobniej pracy nie znajdzie i zasili grono bezrobotnych. Po drugie osoby podejmujące pracę najprawdopodobniej relatywnie często będą podejmowały zajęcia mało atrakcyjne płacowo i mało rozwojowe, gdyż w warunkach wysokiego bezrobocia i przy posiadanym wykształceniu ogólnokształcącym trudno będzie im znaleźć dobrą pracę. Wyższa skłonność do podejmowania pracy bez kontynuowania nauki po ukończeniu szkoły średniej wśród młodych z obszarów o wysokiej stopie bezrobocia wynikać może także z obawy przed postępującym bezrobociem, a w konsekwencji jeszcze większymi trudnościami ze znalezieniem pracy za kolejne kilka lat, tj. po ukończeniu studiów.

Warto też wspomnieć o respondentach, którzy w omawianym pytaniu zdeklarowali, że po ukończeniu szkoły średniej zamierzają „robić coś innego", lecz zarazem należy zaznaczyć, iż takiego wyboru dokonało zaledwie 0,9 proc. respondentów (4 osoby) z I grupy powiatów i 1,5 proc. respondentów (6 osób) z II grupy powiatów. Maturzyści 
z powiatów o niskiej stopie bezrobocia tuż po maturze zamierzają zrobić sobie rok przerwy, w czasie którego będą pracować, a następnie planują kontynuować kształcenie. Natomiast młodzież z powiatów o wysokiej stopie bezrobocia zamierza m.in. wychowywać dziecko, koncertować czy prowadzić własną działalność gospodarczą. Taki stan rzeczy może również wynikać z sytuacji na lokalnym rynku pracy - młodzież zamieszkująca I grupę powiatów może pozwolić sobie na rok pracy, a następnie powrót do nauki, a młodzież z II grupy powiatów, mówiąc „robić coś innego”, ma na myśli samodzielne zorganizowanie sobie miejsca pracy.

Ponieważ większość respondentów tuż po ukończeniu liceum zamierza nadal się kształcić (zarówno jednocześnie pracując, jak i bez podejmowania zatrudnienia), ankietowanych zapytano również o to, w jakim miejscu chcą podjąć studia. Odpowiedzi respondentów dostarczyły bardzo istotnych informacji na temat kierunków migracji edukacyjnych ankietowanej młodzieży (rys. 2).

Rysunek 2. Deklarowane miasta zamierzonych studiów młodzieży objętej badaniem

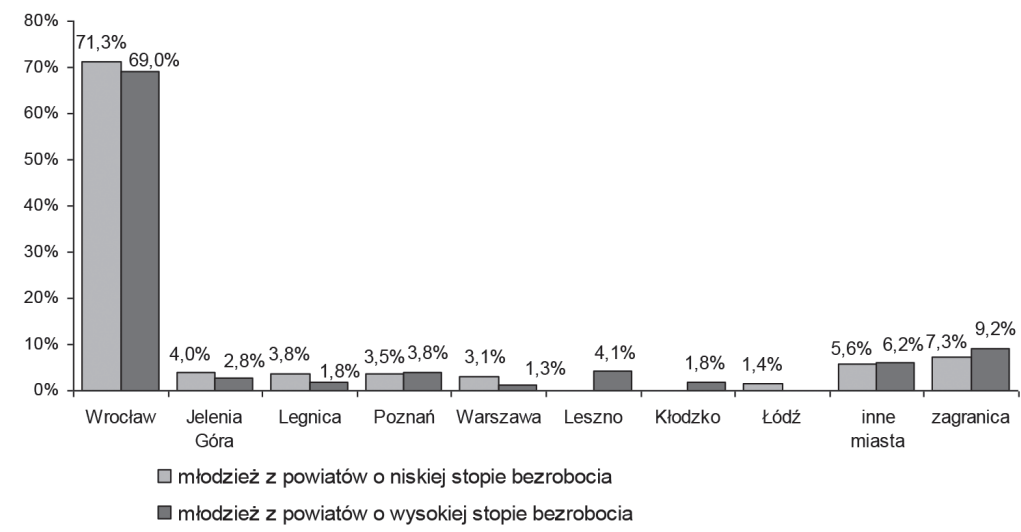

Źródło: Opracowanie własne na podstawie wyników badań. 
Zdecydowana większość młodzieży z obu objętych badaniem grup powiatów, mającej zamiar po maturze nadal się kształcić, planuje podjąć dalszą edukację we Wrocławiu. Jest to 71,3 proc. osób z I grupy powiatów, które chcą kontynuować naukę, oraz 69 proc. młodzieży z II grupy powiatów.

Drugą pod względem liczebności grupę (choć już zdecydowanie mniejszą) wśród osób zamierzających po zdaniu matury kontynuować naukę stanowi młodzież planująca podjęcie dalszej edukacji za granicą. W przypadku młodych zamieszkujących I grupę powiatów jest to 7,3 proc. badanych, którzy będą się dalej uczyć, zaś spośród maturzystów pochodzących z II grupy powiatów takiej odpowiedzi udzieliło 9,2 proc. respondentów.

Wśród pozostałych miast wskazywanych przez maturzystów zarówno z I, jak i z II grupy powiatów jako miejsca dalszej edukacji pojawiały się: Jelenia Góra (odpowiednio 4,o proc. i 2,8 proc. maturzystów deklarujących chęć dalszej edukacji), Legnica (3,8 proc. i 1,8 proc.), Poznań (3,5 proc. i 3,8 proc.), Warszawa (3,1 proc. i 1,3 proc.). Młodzież z I grupy powiatów zamierza podjąć dalsze kształcenie także w Łodzi (1,4 proc.), natomiast część respondentów Z II grupy powiatów wskazywała też Leszno (4,1 proc.) oraz Kłodzko (1,8 proc.).

Ankietowani sporadycznie wskazywali również inne polskie miasta, w których zamierzają kontynuować kształcenie - w analizie zostały one ujęte łącznie jako kategoria „inne miasta”. Takie preferencje deklaruje 5,6 proc. respondentów Z I grupy powiatów oraz 6,2 proc. młodzieży zamieszkującej II grupę powiatów.

Generalnie jednak wyniki wskazują, że Wrocław stanowi miejsce drenażu edukacyjnego znaczącej części młodzieży zamieszkującej objęte badaniem powiaty województwa dolnośląskiego, bez względu na sytuację na lokalnych rynkach pracy. Ukazuje to skalę migracji edukacyjnej młodzieży z obszarów województwa dolnośląskiego 
w kierunku Wrocławia, a tym samym słabość oddziaływania ośrodków akademickich znajdujących się poza aglomeracją wrocławską.

Niezmiernie ważnym, jeśli nie najważniejszym badanym zagadnieniem były zamiary młodzieży dotyczące przyszłego (docelowego) miejsca zamieszkania (rys. 3). Odpowiedzi respondentów właśnie na to pytanie pokazują, że migracje edukacyjne w zdecydowanej większości przekształcają się w migracje definitywne. Natomiast wybierane przez respondentów miasta studiów wskazywane są również jako miejsca stałego zamieszkania. Udzielając odpowiedzi, respondenci mogli wskazać jeden z zaproponowanych wariantów: „miejscowość dotychczasowego zamieszkania”; „miasto poza miejscem zamieszkania, ale w tym samym województwie”; „wieś poza miejscem zamieszkania, ale w tym samym województwie”; „miasto w innym województwie”; „wieś w innym województwie”; „za granicą”.

Rysunek 3. Deklarowane miejsce stałego zamieszkania respondentów po ukończeniu nauki i podjęciu pracy

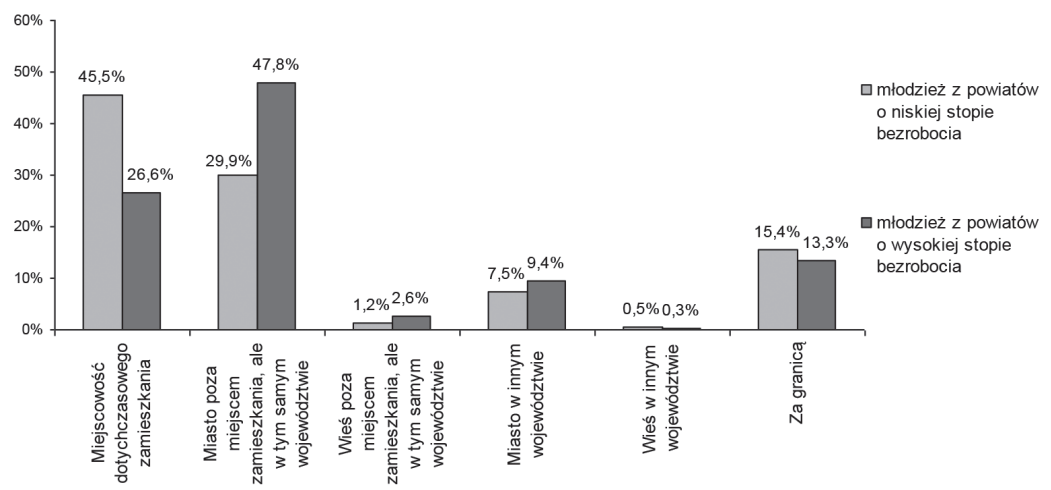

Źródło: Opracowanie własne na podstawie wyników badań.

Zasadnicza różnica w wyborze przyszłego - stałego - miejsca zamieszkania jest widoczna w obrębie dwóch głównych preferowanych rodzajów odpowiedzi: „dotychczasowe miejsce zamieszkania” oraz 
„miejsce poza obszarem zamieszkania, ale w tym samym województwie”. W miejscowości dotychczasowego zamieszkania planuje pozostać 45,5 proc. młodzieży z powiatów o niskiej stopie bezrobocia i tylko 26,6 proc. badanych z powiatów o wysokiej stopie bezrobocia.

Adekwatnie do tego młodzież pochodząca z obszarów cechujących się trudną sytuacją na lokalnych rynkach pracy zdecydowanie częściej deklaruje, że po ukończeniu edukacji i podjęciu stałej pracy zamieszka w mieście poza miejscem dotychczasowego zamieszkania, jednak w województwie dolnośląskim - taki wariant odpowiedzi wskazało 47,8 proc. Z kolei wśród badanych pochodzących z powiatów o najniższym bezrobociu wariant „miasto poza miejscem zamieszkania, ale w województwie dolnośląskim” wybrało 29,9 proc. badanych.

Znaczna część ankietowanej młodzieży deklaruje, że w przyszłości na stałe zamieszka „za granicą”. Takiej odpowiedzi udzieliło 15,4 proc. respondentów pochodzących z I grupy powiatów oraz 13,3 proc. badanych z II grupy powiatów.

W miastach położonych w województwach innych niż dolnośląskie planują zamieszkać podobne liczebnie grupy osób objętych badaniem pochodzących $z$ dwóch analizowanych grup powiatów. Jest to 7,5 proc. młodzieży z I grupy powiatów i 9,4 proc. ankietowanych z II grupy powiatów.

Wyniki badań wykazały, że bardzo niewielka liczba badanych jest skłonna w przyszłości zamieszkać na wsi poza miejscem zamieszkania, ale w województwie dolnośląskim - odpowiedzi takiej udzieliło 1,2 proc. ankietowanych $\mathrm{z}$ I grupy powiatów oraz 2,6 proc. respondentów z II grupy powiatów. Natomiast na wsi w innym województwie w przyszłości zamierza zamieszkać odpowiednio o,5 proc. i o,3 proc. respondentów, co stanowi jeszcze mniejszy odsetek wszystkich ankietowanych.

Tak kształtujące się wyniki zrealizowanego badania dostarczają istotnych informacji o potencjalnej skali migracji definitywnej 
młodzieży z województwa dolnośląskiego. Pozwalają stwierdzić, że sytuacja na rynku pracy jest istotnym czynnikiem w podejmowaniu decyzji migracyjnych przez młodzież z wybranych ośrodków województwa dolnośląskiego. A młodzi ludzie, którzy obecnie zamieszkują obszary charakteryzujące się trudną sytuacją na lokalnych rynkach pracy, są bardziej skłonni do podejmowania migracji definitywnych w porównaniu z młodzieżą zamieszkująca obszary, gdzie o pracę znacznie łatwiej. Nie ulega też wątpliwości, że udział osób zamierzających wyjechać za granicę uznać należy za stosunkowo duży. Wydaje się również, że może on ulec znacznemu powiększeniu po konfrontacji z realiami rynku pracy. Preferencje dotyczące emigracji zagranicznej na obszarze o niższym bezrobociu tłumaczyć można w pewnym sensie wyższymi aspiracjami, ale i ograniczonymi bodźcami do migracji wewnętrznej - bowiem w jakim celu i do jakich ośrodków regionalnych w Polsce miałaby wyjeżdżać młodzież np. z Wrocławia, ale także częściowo - z Jeleniej Góry i z terenu zagłębia miedziowego? Natomiast młodzież z obszarów o większym bezrobociu jest bardziej mobilna, ale raczej w układzie „obszar zamieszkania - Wrocław”, gdyż już taka mobilność (w jej mniemaniu) daje istotny progres edukacyjny, zawodowy i jakościowy.

Znaczna część ankietowanej młodzieży deklaruje, że po zakończeniu edukacji i podjęciu pracy na stałe zamieszka w mieście poza miejscem obecnego zamieszkania, ale w województwie dolnośląskim. Aby sprawdzić, do jakich dolnośląskich miast zamierzają migrować respondenci, ten właśnie wariant odpowiedzi poddano głębszej analizie (rys. 4).

Zdecydowana większość młodych ludzi uczestniczących w badaniu na cel definitywnych migracji wybiera Wrocław. Wśród młodych planujących definitywne migracje do miast w obrębie województwa dolnośląskiego w przypadku młodzieży zamieszkującej I grupę powiatów taką deklarację złożyło 86,4 proc. badanych, natomiast wśród 
respondentów pochodzących z II grupy powiatów 87,9 proc ankietowanych. Warto w tym miejscu podkreślić, że wśród 86,4 proc. respondentów z I grupy powiatów znajdują się jedynie osoby z powiatu m. Jelenia Góra i lubińskiego, gdyż badani z powiatu m. Wrocławia już go zamieszkują, przez co względne nasilenie tej migracji jest jeszcze większe.

Rysunek 4. Deklarowane miasta stałej migracji młodzieży w obrębie województwa dolnośląskiego

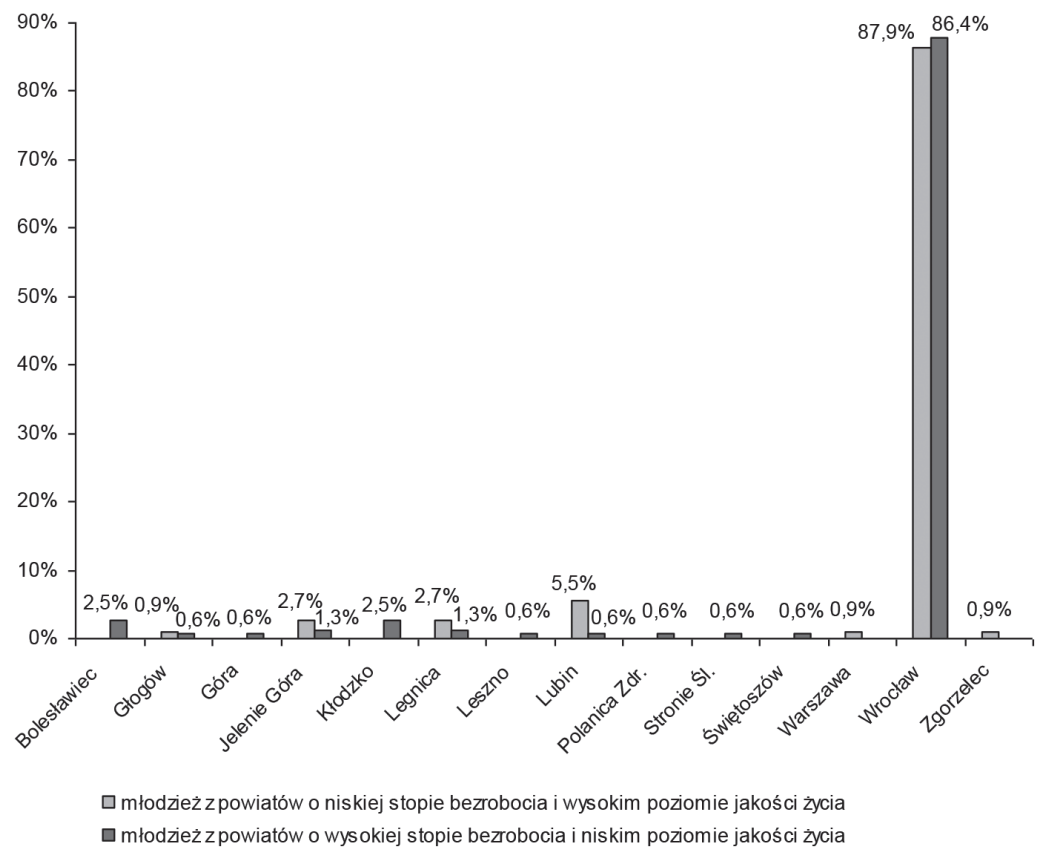

Źródło: Opracowanie własne na podstawie wyników badań.

Zamierzona, jednokierunkowa i ogromna skala migracji stałych w obrębie województwa dolnośląskiego jest niepokojąca, gdyż znaczny poziom drenażu młodzieży z objętych badaniem obszarów województwa dolnośląskiego, szczególnie w kierunku Wrocławia, będzie 
prowadzić do wyludniania tych terenów i ich peryferyzacji. A ponieważ jakość życia w lokalnych społecznościach jest zależna w znacznym stopniu od zaangażowania młodzieży, ten relatywnie duży ubytek młodych ludzi pogłębi niewątpliwie problem rozwoju obszarów, z których oni pochodzą.

W toku realizowanego badania możliwe stało się również określenie głównych motywów definitywnego opuszczania rodzinnych stron przez młodych ludzi (rys. 5). W tej kwestii respondenci zostali poproszeni o wybranie jednej, najważniejszej ich zdaniem przyczyny podejmowania migracji stałych przez młodzież, spośród następujących: „chęć poprawy sytuacji materialnej i/lub warunków życia własnych lub rodziny”; „brak pracy w miejscu zamieszkania”; „względy rodzinne, np. zawarcie małżeństwa”; „chęć rozwoju zawodowego i osobistego”; „chęć poznania innych kultur, regionów, krajów”; „chęć usamodzielnienia się lub niechęć do dalszego mieszkania z rodzicami lub w ich pobliżu”; „ucieczka od środowiska, problemów, rodziny/ znajomych”; „inne powody”.

Kolejnym często wskazywanym uwarunkowaniem migracji młodych ludzi jest ich zdaniem „brak pracy w miejscu zamieszkania” ku tej ekonomicznej determinancie znacznie częściej skłaniały się osoby zamieszkujące powiaty cechujące się wysokim bezrobociem (30,3 proc.) niż respondenci z powiatów, gdzie stopa bezrobocia jest najniższa w województwie (21,3 proc.), nie mniej wariant ten wskazywany był stosunkowo często. Zatem brak pracy w opinii ankietowanych zasadniczo sprzyja podejmowaniu migracji.

Natomiast „chęć rozwoju zawodowego i osobistego" jako przyczynę definitywnych migracji młodzieży częściej wskazywały osoby zamieszkujące I grupę powiatów (21,o proc.) niż młodzież pochodząca Z II grupy powiatów (12,6 proc.).

Zdaniem respondentów najistotniejszym czynnikiem skłaniającym młodzież do migracji jest „chęć poprawy sytuacji materialnej i/ 
lub warunków życia własnych lub rodziny" - ten wariant odpowiedzi wskazało 44,9 proc. ankietowanych zamieszkujących powiaty o najniższej stopie bezrobocia w województwie dolnośląskim oraz 46,3 proc. badanych z powiatów cechujących się najwyższą stopą bezrobocia.

Rysunek 5. Główne powody definitywnego opuszczania przez młodych ludzi rodzinnych stron w opinii badanej młodzieży

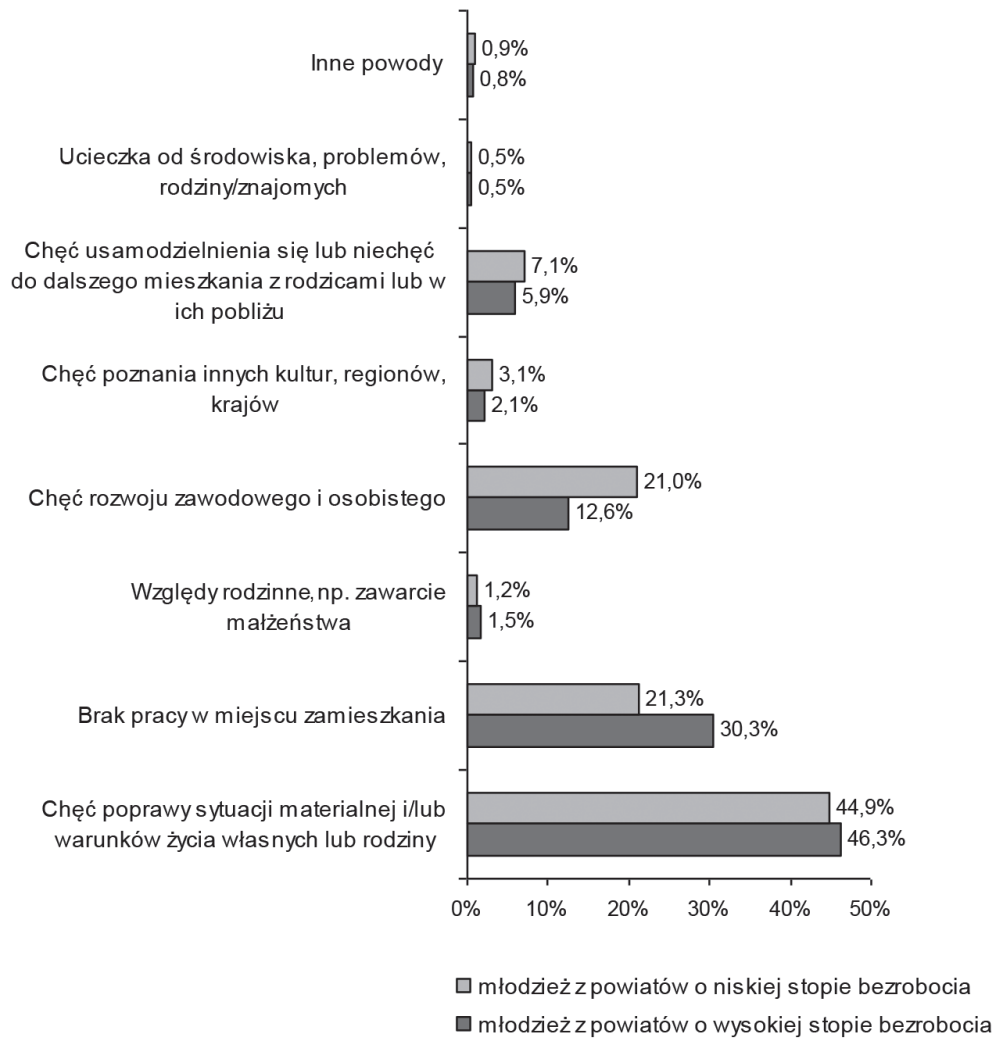

Źródło: Opracowanie własne na podstawie wyników badań.

Pozaekonomiczne czynniki definitywnych migracji młodzieży, do których należą „chęć usamodzielnienia się/niechęć do dalszego 
mieszkania z rodzicami lub w ich pobliżu” czy „chęć poznania innych kultur, regionów, krajów”, a także „względy rodzinne” czy „ucieczka od środowiska, problemów, rodziny czy znajomych”, respondenci wybierali już znacznie rzadziej.

W tym miejscu warto zauważyć, że przyciągające determinanty migracji, takie jak: „chęć rozwoju zawodowego i osobistego”, „chęć usamodzielnienia się” lub „niechęć do dalszego mieszkania z rodzicami lub w ich pobliżu” czy „chęć poznania innych kultur, regionów krajów", silniej oddziałują na respondentów zamieszkujących obszary cechujące się stosunkowo niewielkim poziomem bezrobocia. Z kolei ankietowani z powiatów o trudnej sytuacji na lokalnych rynkach pracy częściej wskazywali czynniki wypychające, do których z pewnością należą „brak pracy w miejscu zamieszkania” oraz „chęć poprawy sytuacji materialnej i/lub warunków życia własnych lub rodziny”.

\section{Podsumowanie}

Zaprezentowane wyniki badań wskazują, że istotna część ankietowanej młodzieży decyduje się na długotrwałe lub definitywne opuszczenie miejsca zamieszkania po ukończeniu szkoły średniej. Odpowiedzi respondentów na pytanie dotyczące ich planów na najbliższą przyszłość pokazują, że ponad 90 proc. ankietowanych z obu grup badanych powiatów zamierza po maturze podjąć edukację na wyższym poziomie. Zaznaczyć tu należy, że blisko trzy czwarte ankietowanych z obu grup powiatów, zamierzających kontynuować edukację, planuje podjąć dalsze kształcenie we Wrocławiu. Odzwierciedla to ogromną skalę migracji edukacyjnych skoncentrowaną w kierunku silnie oddziałującego ośrodka regionalnego.

Wyniki badań wskazują również, że migracje definitywne w zdecydowanie większym stopniu dotyczą młodych ludzi zamieszkujących powiaty o trudnej sytuacji ekonomicznej, gdzie perspektywicznie 
ma zamiar mieszkać jedynie około jedna czwarta spośród badanych maturzystów. Nie ulega więc wątpliwości, że związane z emigracją wyludnienie stanowi i stanowić będzie poważny problem rozwojowy obszarów ich pochodzenia, ponieważ doprowadzi do utraty ogromnej części kapitału ludzkiego. Młodzież pochodząca z obszarów o dużym bezrobociu znacznie częściej niż ta pochodząca z obszarów charakteryzujących się stosunkowo dobrą sytuacją ekonomiczną planuje w przyszłości zamieszkać w mieście poza obecnym miejscem zamieszkania, jednak w województwie dolnośląskim, najczęściej we Wrocławiu, wykazując w ten sposób wysoką skłonność do definitywnych migracji wewnętrznych. Natomiast młodzi ludzie z powiatów, gdzie stopa bezrobocia jest stosunkowo niska, w blisko połowie zamierzają pozostać w miejscowości dotychczasowego zamieszkania. Jednak również w tej grupie badanych blisko 2/3 zamierzających na stałe zamieszkać poza miejscem zamieszkania, ale w miastach województwa dolnośląskiego, na cel migracji definitywnych wskazuje Wrocław.

W wyniku przeprowadzonego badania ustalono także, że głównymi czynnikami determinującymi opuszczanie miejsc zamieszkania przez młodzież są czynniki stricte ekonomiczne. W tym miejscu podkreślić należy, iż w odniesieniu do młodzieży zamieszkującej obszary cechujące się trudną sytuacją na lokalnych rynkach pracy i niskim poziomem jakości życia, w większym stopniu działają czynniki wypychające z miejsc obecnego zamieszkania, zwłaszcza brak możliwości zatrudnienia. Z kolei na młodzież z powiatów o stosunkowo niskiej stopie bezrobocia i wysokim poziomie jakości życia silniej oddziałują czynniki przyciągające do nowych miejsc zamieszkania, przejawiające się chociażby w możliwości rozwoju osobistego czy zawodowego.

Ze względu na fakt, iż obszary wiejskie oraz małe i średnie miasta (w tym większość ośrodków powojewódzkich) nie są w stanie zaoferować zatrudnienia ogromnej liczbie osób uzyskujących wyższe wykształcenie, znaczna część absolwentów studiów nie jest w stanie 
podjąć pracy zgodnej ze swoim wykształceniem i aspiracjami, dlatego szuka jej gdzie indziej. Dokonuje się przy tym zarówno drenaż, jak i marnotrawstwo „mózgów”. Warto zauważyć, że jeszcze kilkanaście lub nawet kilka lat temu ten drenaż miał mniejszą skalę, gdyż istotnie mniej osób studiowało, i dokonywał się raczej dopiero po studiach młodzież podejmowała decyzje o definitywnym opuszczeniu peryferyjnych obszarów swojego pochodzenia dopiero po rozpoznaniu warunków na regionalnym rynku pracy. Obecnie, kiedy problemy absolwentów studiów na rynku pracy stały się - poprzez ich „nadprodukcję” - bardziej zauważalne, do transferu młodzieży o raczej definitywnym charakterze dochodzi już w momencie wyboru studiów. Podjęcie studiów stanowi tym samym nie główny cel, ale jedynie pierwszy - i niekluczowy - etap zamierzonej migracji.

Tak kształtująca się rzeczywistość pomaturalnych migracji młodzieży wymaga również przeorientowania działań w sferze edukacji i rynku pracy, gdyż okazuje się, że możliwości oddziaływania na wyjeżdżającą młodzież generalnie znikają bądź przynajmniej ulegają znacznemu ograniczeniu już w momencie podjęcia studiów poza obszarem pochodzenia, a w zasadzie nawet jeszcze wcześniej - już w momencie ich wyboru przez absolwentów szkół średnich.

Nietrudno również zauważyć, że zarysowany w opracowaniu proces masowego drenażu młodzieży poskutkuje dramatycznym wyludnieniem większości mniejszych ośrodków i prawie całości obszarów peryferyjnych. Jego konsekwencją będą nie tylko ogromne zmiany w strukturze wieku ludności, objawiające się odwróceniem piramidy wieku i nieodległą w czasie dominacją ludzi starszych. Problemem staną się polityka społeczna i utrzymanie infrastruktury, a także finansowanie opieki nad ludźmi starszymi, z czym zubożałe fiskalnie samorządy mogą sobie nie poradzić bez zmiany polityki państwa. 


\section{Summary}

The nature and direction of migration of post-secondary education of youth on the example of Lower Silesia

With the massification of higher education, intensified educational migrations youth associated with taking study outside their place of residence. The study contains partial results of research conducted among student's last classes of secondary schools in Lower Silesia. The presented data relate to preferred directions of migration "study" as well as the intended target places of residence Lower Silesia graduates. As evidenced by the results of research the vast majority of young people from the province of Lower Silesia are going to study in Wroclaw. At the same time comparing the preferred study centers and places of residence of the target indicates a definitive and not strictly educational nature of the intended migration. This suggests that the educational youth drainage is also the beginning of exile definitive, directing mostly to large and perceived as attractive regional centers. The results of completed studies indicate that the main factors of this process are the economic factors, which include, above all, a wider range of labor market and the possibility of improving their living conditions and family. Keywords: educational migration, migration definitive, youth, labor market 